\title{
A Family with Vocal Cord Paralysis Associated with GDAP1 Mutation in Giresun, Turkey
}

\author{
Türkiye'nin Giresun İlinde GDAP1 Mutasyonuna Bağlı Vokal Kord Paralizisi
} Olan Bir Aile

\author{
Nilgün Erten1, Esra Battaloğlu², Alperen Erdoğan², Erdal Seren 3 \\ 1 Giresun University Faculty of Medicine, Department of Neurology, Giresun, Turkey \\ 2Boğaziçi University Faculty of Medicine, Department of Molecular Biology and Genetics, İstanbul, Turkey \\ ${ }^{3}$ Giresun University Faculty of Medicine, Department of Otorhinolaryngology, Giresun, Turkey
}

\section{Summary}

A Turkish family living in northern Turkey with hereditary neuropathy is described herein. The current study presents two sisters with severe proximal and distal motor deficits, anatomic deformities, such as pes cavus and claw hand, dependency on wheelchairs, who were born to parents with fifth-degree consanguinity, and developed vocal cord paralysis in the follow-up. The genetic analysis revealed that the siblings were homozygous for p.Q38X (c.112C > T) mutation in the GDAP1 gene. There are rare reports of vocal cord paresis in patients with hereditary neuropathy, which may result in respiratory difficulty in the clinical course. The aim of the current study was to highlight the importance of genetic studies that predict the development of vocal cord paralysis, which could reduce the expected life span in patients with hereditary neuropathy, a condition commonly encountered in our region owing to consanguineous marriage.

Keywords: Vocal cord paralysis, hereditary neuropathy, GDAP1 gene

$\ddot{\mathbf{O} z}$

Türkiye'nin kuzeyinde yaşayan herediter nöropatisi olan bir Türk aile tanımlanmıştır. Ciddi proksimal ve distal motor defisitleri olan, pes cavus ve pençe el gibi deformiteleri bulunan, tekerlekli sandalyeye bağımlı, takiplerinde vokal kord paralizisi gelişen, anne ve babaları beşinci dereceden akraba olan iki kız kardeş sunulmuştur. Kardeşlerin genetik analizlerinde GDAP1 geninde p.Q38X (c.112C>T) homozigot mutasyonu taşıdıkları gösterilmiştir. Herediter nöropatili hastaların klinik seyirlerinde solunum zorluğuna neden olabilecek vokal kord paralizisinin nadir de olsa geliştiğini bildirmiş yayınlar mevcuttur. Biz bu yazımızla bölgemizde akraba evliliklerinin yaygın olması nedeni ile sık gördüğümüz herediter nöropatili olgularda beklenen yaşam süresini kısaltabilecek vokal kord paralizisinin gelişebileceği hakkında önceden fikir verebilecek genetik çalı̧̧maların önemini vurgulamak istedik.

Anahtar kelimeler: Vokal kord paralizisi, kalıtsal nöropati, GDAP1 geni

\section{Introduction}

Hereditary neuropathies are rarely encountered disorders and their phenotypic features are heterogeneous. Although the clinical findings demonstrate variability from one patient to another, they are characterized by slow-progressing weakness and atrophy in peroneal and other distal muscles. It can sometimes cause severe disability. The disease rarely affects the respiratory muscles and may negatively affect the expected life span. There are many types of Charcot-Marie-Tooth (CMT) neuropathies, which can be distinguished by age at onset, inheritance pattern, severity, and the presence of axon or myelin defects.

In general, demyelinating forms with the predominance of deceleration in the velocity of nerve conduction are classified as CMT type 1 (HMSN-1), and those characterized by axonal involvement with normal or slightly decreased nerve conduction 
are classified as CMT type 2 (HMSN-2). The inheritance pattern is autosomal dominant or autosomal recessive in both types. CMT-2 is less frequent than CMT-1 and the onset of disease is at later ages. Although CMT-2 exhibits electrophysiologic and histopathologic features of axon loss, the clinical features are similar to CMT-1 $(1,2)$. The autosomal recessive form of CMT-1 has been labeled CMT-4. The disease forms with childhood onset that exhibit demyelinating features, which are considered to have an autosomal recessive inheritance pattern, are called HMSN-3 (Dejerine-Sottas disease) (2).

The involvement of vocal cords is rare; however, it is a characteristic feature for hereditary neuropathy. Some CMT types with vocal cord involvement include CMT2C, CMT2T, CMT4A, AR-CMT2, X-CMT, HNPP, CMT1A, CMT1D, CMT2A2 caused by TRPV 4, GDAP1, GJB1, PMP 22, EGR2, and MFN2 gene mutations, respectively $(1,3,4,5,6,7,8)$.

A comprehensive study suggested that vocal cord paresis was an important symptom that decreased life expectancy by causing disability, aspiration pneumonia, and respiratory failure in hereditary neuropathies associated with the gangliosideinduced differentiation-associated protein 1 (GDAP1) gene mutation (9).

Although no studies have been conducted regarding the incidence of hereditary neuropathy in our geographic area, which has a high frequency of consanguineous marriages, it can be said that the incidence is high based on the experiences of other authors. The aim of the current report was to present two female siblings with hereditary neuropathy associated with the GDAP1 mutation, who were born to consanguineous parents, and developed vocal cord paralysis during their follow-up.

\section{Case Report}

Two sisters with hereditary neuropathy who were born to parents with fifth-degree consanguinity living with their family in northern Turkey are reported herein. The pedigree of the family is shown in Figure 1. The siblings learned to walk late when compared with their peers. They had difficulty in running in early childhood. Both siblings developed muscle atrophy in the first and second decades, which was more prominent in the distal muscles of the upper and lower extremities, and pes cavus and clawhand deformities became apparent in both siblings in the first decade. In both siblings, proximal muscle weakness in the lower extremities progressed during the second decade and both became

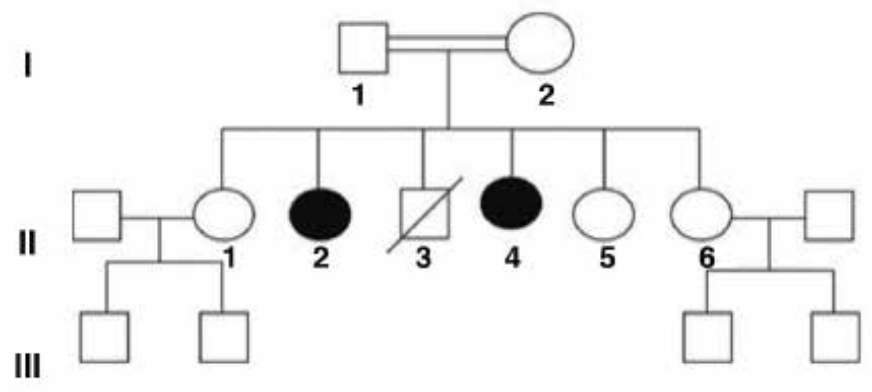

Figure 1. Pedigree of the family reported in the present study dependent on wheelchairs late in the second decade. Both siblings had hoarseness that manifested in the third decade and worsened from time to time. The patients sometimes experienced a choking feeling while eating and had episodes of coughing, despite the absence of dysphagia. They developed exercise intolerance and episodes of shortness of breath. The siblings did not have sensorial symptoms.

The clinical findings of the patients are presented in Table 1. The physical examinations of the older (II2) and younger (II4) siblings revealed muscle weakness in all four extremities, which were more prominent in the distal parts, and amyotrophia that resulted in pes cavus and claw-hand deformities. Deep tendon reflexes could not be obtained. A sensorial examination revealed normal findings. The younger sibling (II4) had mild dystonia. An examination with a flexible laryngoscope revealed bilateral vocal cord paralysis in the older sibling (II2) and left vocal cord paralysis in the younger sibling (II4) (Figure 2).

The median, ulnar, tibial, and peroneal combined action potentials could not be obtained in either of the affected siblings. Electroneuronagraphy revealed a lack of sensorial action potentials in the median, ulnar, and sural nerves, despite the absence of any sensorial symptoms. The results of an electromyography showed a neurogenic pattern in distal and proximal muscles.

The genetic analysis revealed that both siblings (II2, II4) were homozygous for the GDAP1 gene c.112C>T, p.Q38X
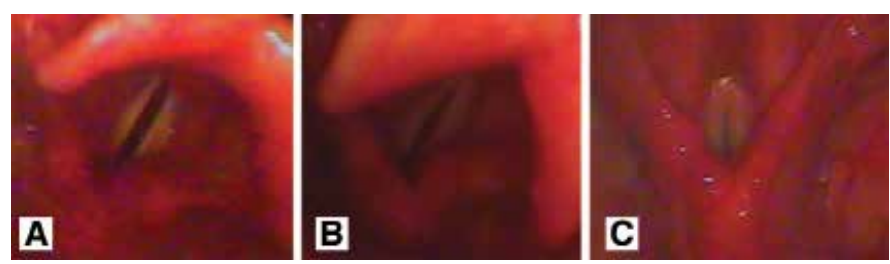

Figure 2. The vocal cords of the patients demonstrated using flexible indirect laryngoscopy. A) Bilateral vocal cord paralysis, homozygous case of GDAP1 gene c.112C>T,Q38X mutation (II2), B) Left vocal cord paralysis, homozygous case of GDAP1 gene c.112C>T,Q38X mutation (II4), C) Normal, heterozygous case of GDAP1 gene c.112C>T,Q38X mutation (II5)

\begin{tabular}{|c|c|c|}
\hline & II2 & II4 \\
\hline Age (years)/sex & $40 / \mathrm{F}$ & $36 / \mathrm{F}$ \\
\hline Age of walking & 20 months & 20 months \\
\hline Proximal UL weakness & ++ & + \\
\hline Distal UL weakness & +++ & +++ \\
\hline Proximal LL weakness & ++ & ++ \\
\hline Distal LL weakness & +++ & +++ \\
\hline Reflexes & Absent & Absent \\
\hline Functional disability UL & Claw-hand & Claw-hand \\
\hline Functional disability LL & WB & WB \\
\hline
\end{tabular}


mutation. The mother (I1), father (I2), and other sibling (II5) were heterozygous for the same mutation. Two healthy siblings (II1 and II6) were not carrying the causative mutation.

\section{Discussion}

The severity of the clinical picture and age of symptoms at onset vary between patients with hereditary neuropathy. Voice change can be an initial symptom in severe cases, but vocal cord paralysis is usually observed in the advanced stages of the disease. The existence of vocal cord paralysis in the whole clinical picture of hereditary neuropathy can be regarded as the indicator of the disease severity (9). Various studies have reported the co-existence of vocal cord paralysis in different types of hereditary neuropathy $(3,4,5,6,7,8)$.

The patients with hereditary neuropathy reported herein who developed vocal cord paralysis were homozygous for the GDAP1 gene c. $112 \mathrm{C}>\mathrm{T}$ mutation in the genetic analysis. Although there is limited knowledge about the functions of the GDAP1 gene, it is known to encode a protein that is highly expressed in the central and peripheral nervous system, particularly in Schwann cells (10). GDAP1 is an integral membrane protein of the outer mitochondrial membrane and its overexpression was shown to induce mitochondrial fragmentation. The gene is known to regulate mitochondrial function and plays a significant role in the myelination of peripheral nerves (11).

Some studies have suggested that the clinical picture in different types of hereditary neuropathy associated with GDAP1 gene mutations is accompanied by vocal cord paralysis $(6,9,12)$. Furthermore, one study reported death associated with respiratory failure caused by vocal cord paralysis (9).

In different types of hereditary neuropathy associated with GDAP1 gene mutation, the clinical appearance is characterized by muscle weakness that starts from the distal muscles, and intermittent dysphonia episodes can be observed in later stages of the disease, which can become permanent (12) and eventually lead to respiratory failure (9).

In conclusion, available genetic studies have shown a relationship between genetic mutations and vocal cord paresis. Thus, it is possible to predict which patients with hereditary neuropathy might develop respiratory difficulty during their clinical courses. Therefore, it is possible to exercise caution against respiratory failure, which could develop during the course of this disease. This suggests that genetic studies must be performed to establish the diagnosis in patients with hereditary neuropathy and predict the prognosis.

\section{Acknowledgements}

The authors thank the CMT family for their cooperation during the study. The study is partially supported by Boğaziçi University Research fund with project number 09B101P.
Informed Consent: A consent form was filled out by all participants, Concept: Nilgün Erten, Design: Nilgün Erten, Data Collection or Processing: Nilgün Erten, Erdal Seren, Analysis or Interpretation: Esra Battaloğlu, Alperen Erdoğan, Literature Search: Nilgün Erten, Writing: Nilgün Erten, Peer-review: Externally peer-reviewed, Conflict of Interest: No conflict of interest was declared by the authors, Financial Disclosure: The authors declared that this study has received no financial support.

\section{References}

1. 2 July 2014. Available from: http://neuromuscular.wustl.edu/time/hmsn html\#2c\#2c

2. Reilly MM. Classification and diagnosis of the inherited neuropathies. Ann Indian Acad Neurol 2009;12:80-88.

3. Dyck PJ, Litchy WJ, Minnerath S, Bird TD, Chance PF, Schaid DJ, Aronson AE. Hereditary motor and sensory neuropathy with diaphragm and vocal cord paresis. Ann Neurol 1994;35:608-615.

4. Li Q, Chen M, Liu K, Lin X, Chui D. Vocal cord paresis and probable X-linked Charcot-Marie-Tooth disease with novel GJB1 mutation. Int J Neurosci 2010;120:731-734.

5. Pareyson D, Taroni F, Botti S, Morbin M, Baratta S, Lauria G, Ciano C, Sghirlanzoni A. Cranial nerve involvement in CMT disease type 1 due to early growth response 2 gene mutation. Neurology 2000;54:16961698.

6. Stojkovic T, Latour P, Viet G, de Seze J, Hurtevent JF, Vandenberghe A, Vermersch P. Vocal cord and diaphragm paralysis, as clinical features of a French family with autosomal recessive Charot-Marie-Tooth disease, associated with a new mutation in the GDAP1 gene. Neuromuscul Disord 2004;14:261264.

7. Thomas PK, Marques W Jr, Davis MB, Sweeney MG, King RH, Bradley JL, Muddle JR, Tyson J, Malcolm S, Harding AE. The phenotypic manifestations of chromosome 17p11.2 duplication. Brain 1997;120:465-478.

8. Yoshioka R, Dyck PJ, Chance PF. Genetic heterogeneity in Charcot-MarieTooth neuropathy type 2. Neurology 1996;46:569-571.

9. Sevilla T, Jaijo T, Nauffal D, Collado D, Chumillas MJ, Vilchez JJ, Muelas N, Bataller L, Domenech R, Espinós C,Palau F. Vocal cord paresis and diaphragmatic dysfunction are severe and frequent symptoms of GDAP1associated neuropathy. Brain 2008;131:3051-3061.

10. Ammar N, Nelis E, Merlini L, Barisic N, Amouri R, Ceuterick C, Martin JJ, Timmerman V, Hentati F, De Jonghe P. IdentiŞcation of novel GDAP1 mutations causing autosomal recessive Charcot-Marie-Tooth disease. Neuromuscul Disord 2003;13:720-728.

11. Niemann A, Ruegg M, La Padula V, Schenone A, Suter U. Ganglioside-induced differentiation associated protein 1 is a regulator of the mitochondrial network: new implications for Charcot-Marie-Tooth disease. J Cell Biol 2005;170:10671078.

12. Azzedine H, Ruberg M, Ente D, Gilardeau C, Périé S, Wechsler B, Brice A, LeGuern E, Dubourg O. Variability of disease progression in a family with autosomal recessive CMT associated with a S194X and new R310Q mutation in the GDAP1 gene. Neuromuscul Disord 2003;13:341-346. 